\title{
Intraosseous ganglion cyst mimicking chondrosarcoma on MRI: a case report
}

\author{
Eun Hye Seo ${ }^{1}$, Yu Sung Yoon ${ }^{1 *}$ (D) Jang Gyu Cha ${ }^{1}$ and Hee Kyung Kim²
}

\begin{abstract}
Background: The intraosseous ganglia is a benign cyst, rarely locate in the olecranon process. As intraosseous ganglia can mimic malignant bone tumor, computed tomography (CT) is important for diagnosis even when magnetic resonance imaging (MRI) suggests malignant bone tumor, such as chondrosarcoma.

Case presentation: In this paper, we report a 42-year-old woman with intraosseous ganglia in the olecranon process of the ulna. She complained pain in right elbow for 3 weeks. MRI revealed an intraosseous mass which initially diagnosed as chondrosarcoma. However, followed computed tomography (CT) demonstrated scattered intralesional gas and no underlying mineralization, and we can exclude chondrosarcoma from diagnosis.
\end{abstract}

Conclusions: The intraosseous ganglia can mimic bone tumor in MRl; therefore, CT is essential for accurate characterization of bone tumor. Even if MR imaging strongly suggests chondrosarcoma of the bone, CT should be performed as additional study.

Keywords: Olecranon process, Intraosseous ganglia, Chondrosarcoma, Magnetic resonance imaging, Computed tomography

\section{Background}

Intraosseous ganglia are benign cystic lesions consisting of fibrous tissue with extensive mucoid degeneration [1]. These cysts occur less frequently in the upper extremities and olecranon involvement is extremely rare $[1,2]$. It can also cause pain [1-3].

We report a case of intraosseous ganglia in the olecranon process of the ulna, which was initially interpreted as chondrosarcoma with high signal intensity (SI) on T2-weighted fat-suppressed imaging, intermediate SI on T1-weighted imaging, and peripheral lobular enhancement. The patient also exhibited perilesional bone marrow edema, cortical breach, and extraosseous extension, which are common with malignant bone tumors [4].

\footnotetext{
*Correspondence: zick1853@gmail.com

1 Department of Radiology, Soonchunhyang University Bucheon

Hospital, Soonchunhyang University College of Medicine, 170 Jomaru-ro, Bucheon 14584, Republic of Korea

Full list of author information is available at the end of the article
}

However, a final radiologic diagnosis of intraosseous ganglia was reached based on CT before surgery, because scattered gas was observed within the presumed tumor, suggesting endogenous causes such as possession of cavity means hypocellularity and negative pressure due to juxtaarticular location. Its unusual location and MRI findings of intraosseous ganglia mimicking a chondrosarcoma were interesting and informative.

\section{Case presentation}

A 42-year-old woman presented to the outpatient clinic with continuous pain in her right elbow that started 3 weeks prior. She had previously undergone conservative physical therapy at another hospital, but her symptoms were not relieved. The patient reported a Numeric Rating Scale (NRS-11) score of 2 [5]. She had no recent history of trauma or elbow injury, and had no complaints of fever, local heat, or pain in other joints. On physical examination, there was no tenderness, swelling, range of motion limitation, nor external wound on the right original author(s) and the source, provide a link to the Creative Commons licence, and indicate if changes were made. The images or other third party material in this article are included in the article's Creative Commons licence, unless indicated otherwise in a credit line to the material. If material is not included in the article's Creative Commons licence and your intended use is not permitted by statutory regulation or exceeds the permitted use, you will need to obtain permission directly from the copyright holder. To view a copy of this licence, visit http://creativecommons.org/licenses/by/4.0/. The Creative Commons Public Domain Dedication waiver (http://creativeco mmons.org/publicdomain/zero/1.0/) applies to the data made available in this article, unless otherwise stated in a credit line to the data. 
elbow. The patient had no other relevant medical history or abnormal laboratory findings.

Plain radiographs of her right elbow joint demonstrated an osteolytic bone lesion $2.0 \mathrm{~cm}$ in extent in the olecranon process. In AP plain radiograph, it was difficult to accurately detect the lesion, because the olecranon process and the humerus overlapped (Fig. 1a). In lateral projection, we found a geographic osteolytic lesion with partially ill-defined margin at distal portion (Fig. 1b). Contrast enhanced MRI was performed using a 3.0-T MRI scanner (Magnetom Skyra, Siemens, Germany). MRI revealed an approximately $1.5 \times 1.3 \times 2.3$-cm-sized intraosseous mass with
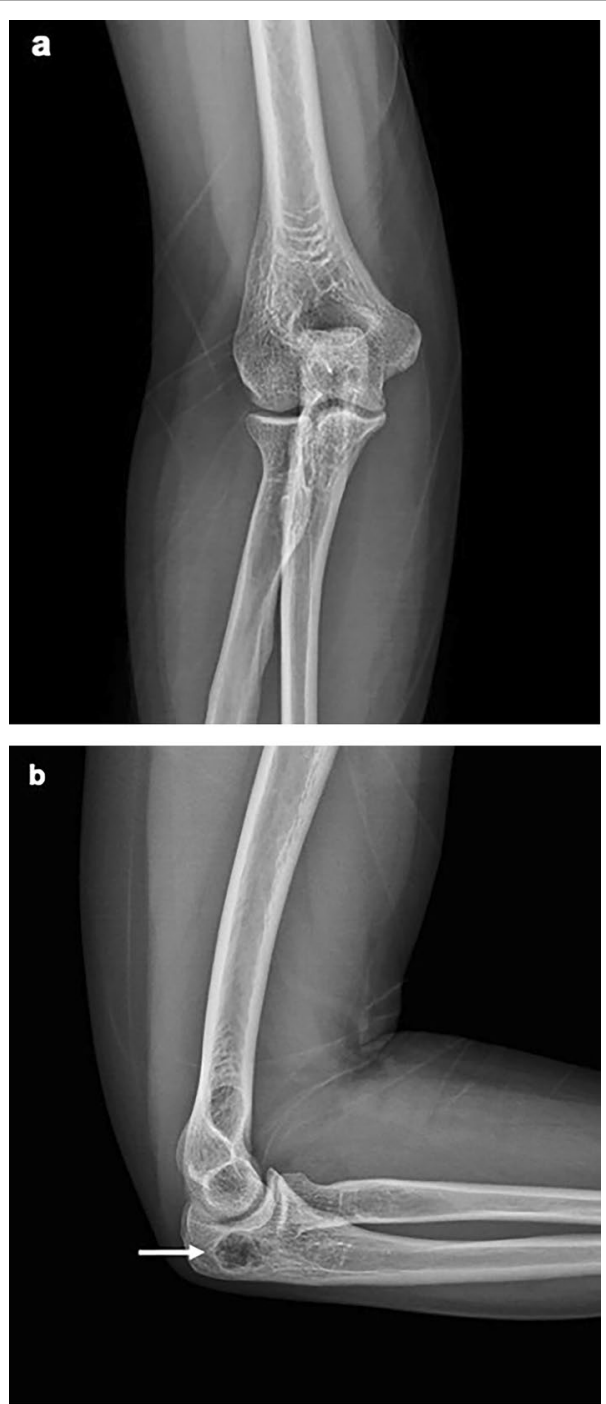

Fig. 1 Right elbow radiograph (lateral projection). a In AP radiograph, it was difficult to find abnormality, because the olecranon process and the humerus overlapped. $\mathbf{b}$ A partially ill-defined osteolytic lesion $2.0 \mathrm{~cm}$ in extent (white arrow) in the olecranon of the right ulna without discernible underlying mineralization marginal lobulation, peripheral lobular enhancement with a regional enhancing portion, and prominent endosteal scalloping. In addition, the lesion had a focal
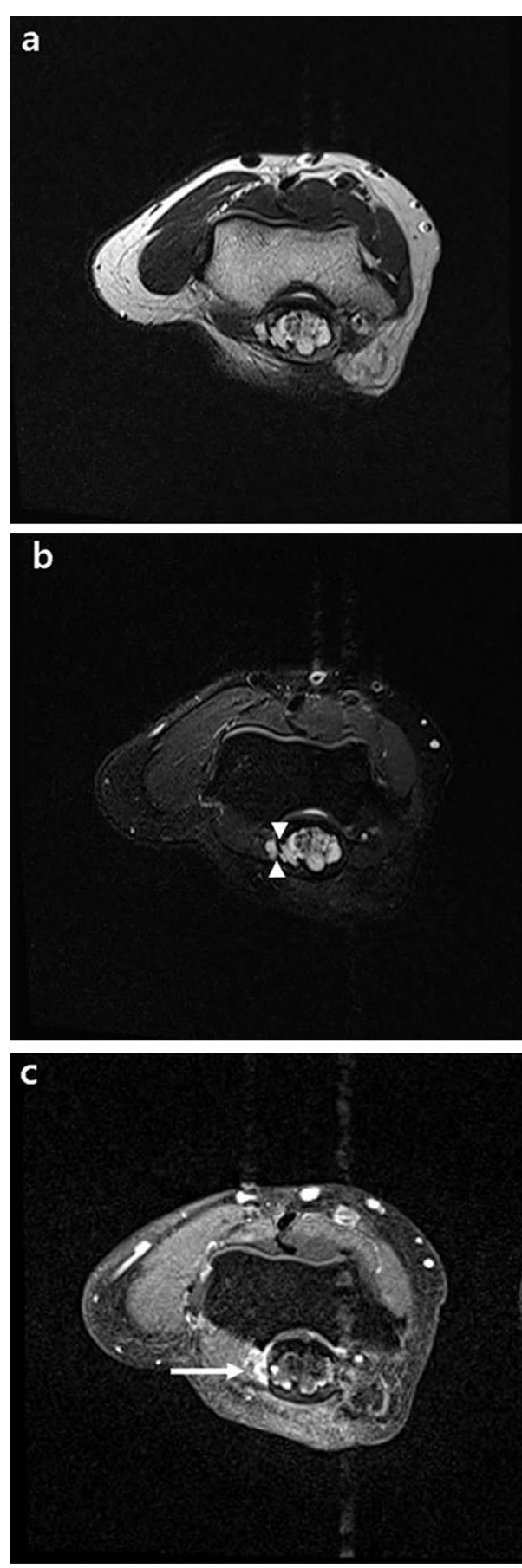

Fig. 2 MRI of the right elbow. In-phase axial T2-weighted (T2W) (a), water only T2W (b), and T1-weighted (T1W) fat-suppressed contrast enhanced (c) images show a $1.5 \times 1.3 \times 2.3 \mathrm{~cm}$ sized intraosseous lesion with endosteal scalloping and peripheral enhancement. The lesion extended through cortical breach (white arrowheads) with enhancing extraosseous component (white arrow) 


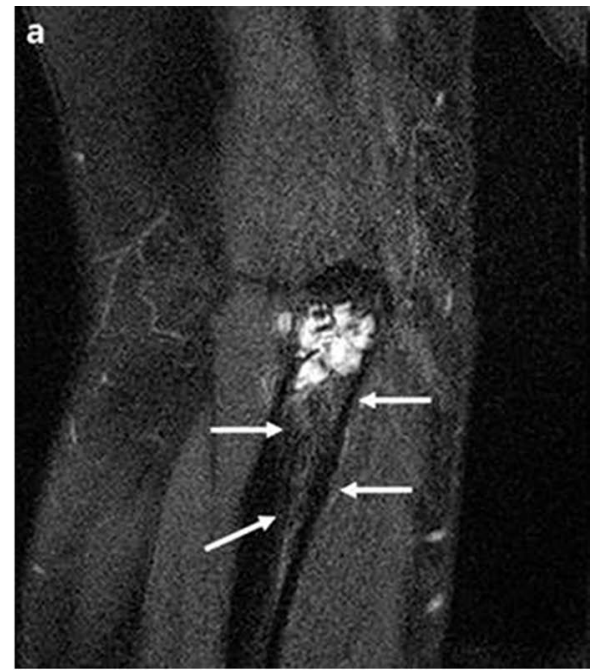

4 Fig. 3 Coronal T2W fat-suppressed (a), T1W (b), and T1W

fat-suppressed contrast-enhanced (c) images showed a mass with lobulated T2 high signal intensity containing a lobular enhancing periphery, which had subtle peritumoral bone marrow edema and enhancement (white arrows)
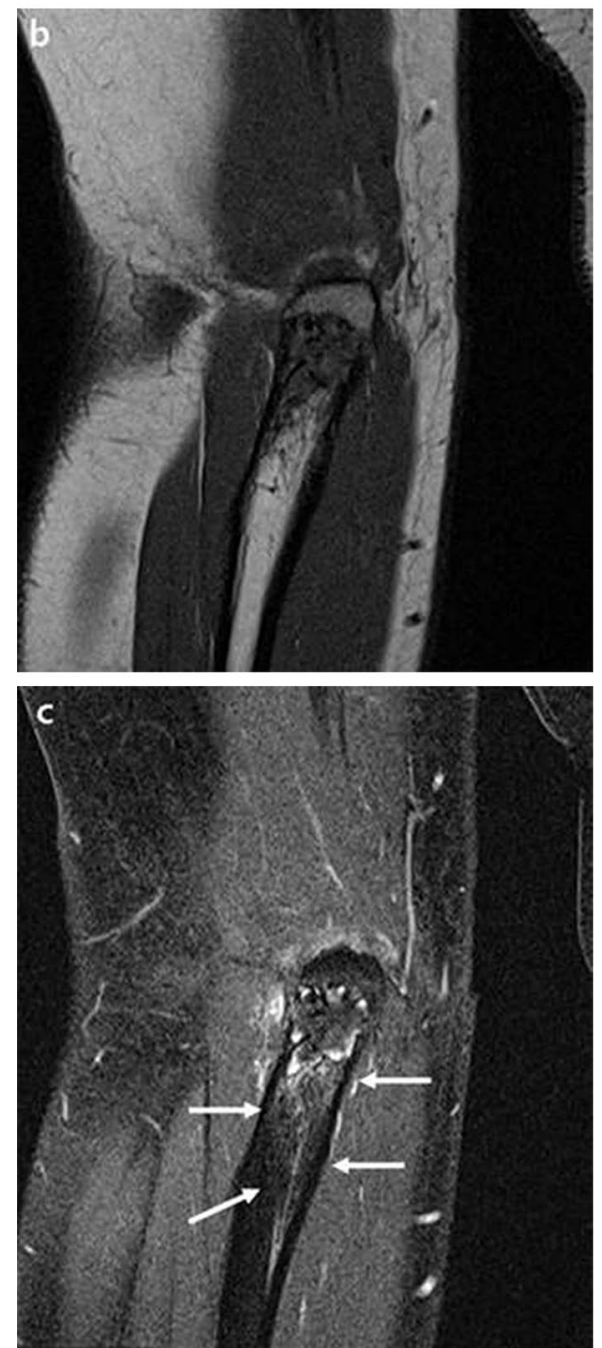

cortical breach with extraosseous extension and perilesional bone marrow edema. There was no definite evidence of joint involvement (Figs. 2, 3, 4).

$\mathrm{CT}$ was performed to clarify the underlying mineralization. On CT, no underlying osteoid or chondroid mineralization was observed except thin septa suggesting hyperdense structure (Fig. 5).

The mass was surgically removed by curettage and elbow pain was relieved after surgery. Pathologic examination of the specimen revealed fragments of fibrous membranous tissue with mucoid degeneration and no epithelial lining (Fig. 6).

\section{Discussion}

Ganglion cysts are fluid-filled lumps that typically develop in the soft tissue along tendons and joints $[6$, 7]. Intraosseous ganglia are rare and commonly located in the tibia, fibula, humerus, ulna, radius, carpal and tarsal bones, acetabulum, and scapular bone [1, 8-11]. The pathophysiology of intraosseous ganglia remains unclear, but it has been suggested that mechanical stress or trauma, synovial herniation, mucoid degeneration, and intramedullary metaplasia of mesenchymal cells may be the main causes $[1,12,13]$.

Gas within the bone can be seen under various conditions, such as emphysematous osteomyelitis, pneumatocyst, osteonecrosis, and postoperative emphysema [14]. The gas results from gas-forming pathogens, exogenous air, and nitrogen gas from soft tissue due to distraction induced negative pressure [14, 15]. In negative-pressure related cases, some lesions have been reported in near completely normal joints without evidence of degenerative changes or a clear connection to the joint space [14]. Maldague et al. [16] believed that the presence of gas in a fracture was due to a lack of tissue, fluid and blood. Likewise, gas within bone tumors suggests a cellular paucity, indicating that reabsorption of gas to surrounding tissues does not occur easily or well liberating environment of nitrogen gas $[1,17]$. In our case, a lack of tissue with mucoid content in the intraosseous ganglia may have contributed to the development of negative pressure, and 

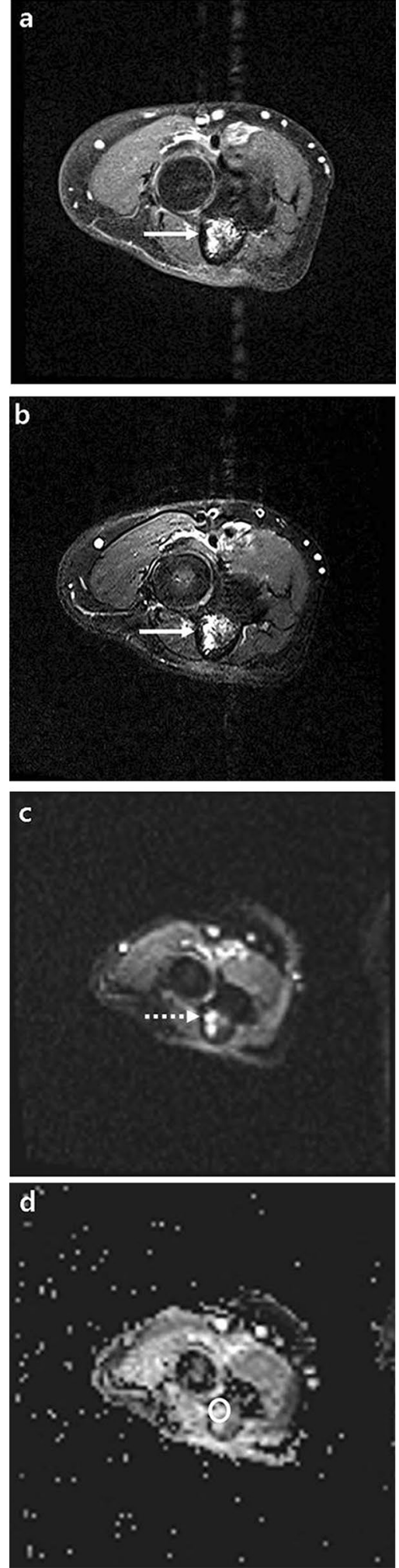

Fig. 4 Axial T2W DIXON (a), T1W fat-suppressed contrast-enhanced (b), high b value $(b=1000)$ diffusion-weighted $(\mathbf{c})$, and ADC map (d) images demonstrated an inferior-side-dominant enhancing solid portion, which showed diffusion restriction on high $b$ value scan (average ADC value; 0.85 , minimum $A D C$ value; 0.62 , maximum $A D C$ value; 1.07 )
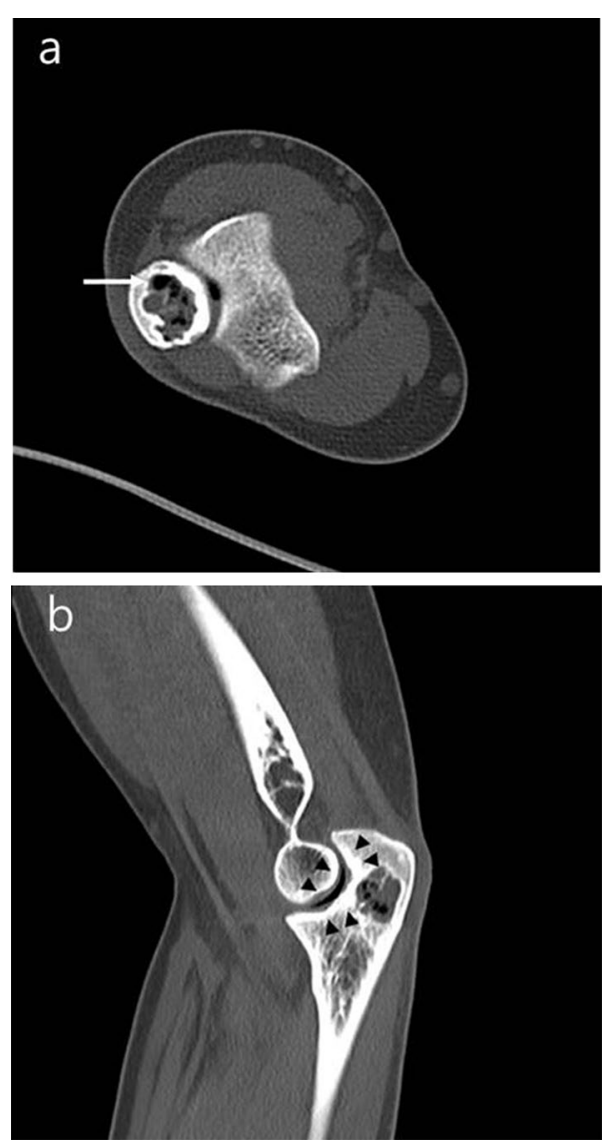

Fig. 5 Axial (a) and sagittal (b) CT scan revealed intralesional gas (white arrow) without evidence of underlying osteoid or chondroid mineralization. Vacuum phenomenon was observed in ulnotrochlear joint with subcortical sclerosis and articular surface dimpling (black arrowheads), but there is no continuation between joint and osteolytic bone lesion

the juxtaarticular location was also affected by negative pressure due to joint movement and maintenance. That negative pressure can result in a decrease in gas solubility. There was adjacent subcortical sclerosis and articular surface irregularities, but no clear connection was observed in CT and MRI. Gas collection was only identified on CT.

According to previous literature, gas in the vertebra or intervertebral discs, and formation of gas due 


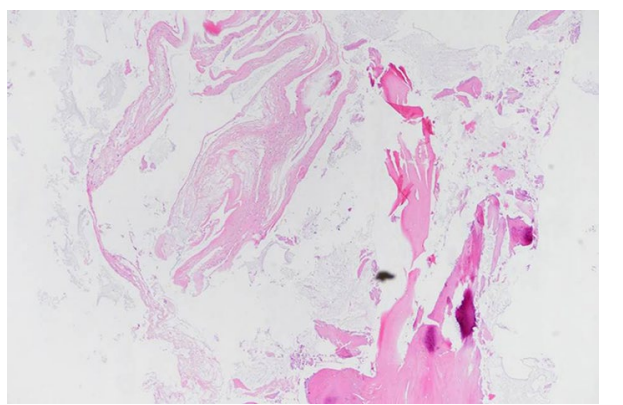

Fig. 6 Microscopic findings of the specimen revealed fragments of fibrous membranous tissue with mucoid degeneration and no epithelial lining (hematoxylin and eosin, $\times 40$ ) to infection can be excluded if there is no evidence of concomitant infection, such as osteomyelitis or paravertebral soft tissue lesions [15]. To the best of our knowledge, no malignant bone tumors with air in the lesion have been reported in the English literature. It is believed that the high-density tissue of malignant tumors contributes to gas reabsorption. In our case, the reasons for a diagnosis of chondrosarcoma based on MRI were as follows: greater than two-thirds endosteal scalloping of the normal cortical thickness, a peripheral lobular enhancing pattern, cortical breach, and an enhancing solid extraosseous component. These findings strongly suggest chondrosarcoma [4]. Even on retrospective MRI review, air was not clearly defined. CT is optimal diagnostic method for intraosseous ganglia, because it can accurately illustrate underlying mineralization and even small amounts of gas $[14,18]$.

\section{Conclusion}

A final radiologic diagnosis of intraosseous ganglion cyst was reached with $\mathrm{CT}$ before surgery based on scattered gas within the lesion. Intraosseous ganglion cysts can mimic bone tumors on MRI; therefore, CT is essential for accurate characterization of bone lesions and differentiation of intraosseous ganglia from chondrosarcoma.

\section{Abbreviations \\ CT: Computed tomography; MRI: Magnetic resonance imaging; SI: Signal intensity.}

\section{Acknowledgements}

Not applicable.

\section{Authors' contributions}

Guarantors of integrity of entire study, Y.S.Y.; study concepts/study design or data acquisition or data analysis/interpretation, E.H.S., Y.S.Y., H.K.K.; manuscript drafting or manuscript revision for important intellectual content, E.H.S, Y.S.Y; agreement to ensure any questions related to the work are appropriately resolved, all authors; literature research, E.H.S.; and manuscript editing, Y.S.Y. All authors read and approved the final manuscript.

\section{Funding}

Supported by the Soonchunhyang University Research Fund.

\section{Availability of data and materials}

Not applicable.

\section{Declarations}

\section{Ethics approval and consent to participate}

The case report was approved and supervised by the ethics committee of the Soonchunhyang University Bucheon Hospital (committee's reference number; 2021-04-014).

\section{Consent for publication}

Informed consent was obtained from the patient.

\section{Competing interests}

The authors declare that they have no competing interest.

\section{Author details}

${ }^{1}$ Department of Radiology, Soonchunhyang University Bucheon Hospital, Soonchunhyang University College of Medicine, 170 Jomaru-ro, Bucheon 14584, Republic of Korea. ²Department of Pathology, Soonchunhyang University Bucheon Hospital, Soonchunhyang University College of Medicine, 170 Jomaru-ro, Bucheon 14584, Republic of Korea.

Received: 14 June 2021 Accepted: 30 December 2021

Published online: 13 January 2022

\section{References}

1. Ehara S, Kattapuram SV, Khurana JS, Rosenberg AE. Case-report 551intraosseous ganglion of olecranon with vacuum phenomenon. Skeletal Radiol. 1989:18(4):329-30.

2. Zarezadeh A, Nourbakhsh M, Shemshaki H, Etemadifar MR, Mazoochian F. Intraosseous ganglion cyst of olecranon. Int J Prev Med. 2012;3(8):581-4.

3. Kovarik J, Drac P. Symptomatic intraosseous ganglion of the trapezium. Case report and literature review. Acta Chir Orthop Tr. 2016:83(4):279-82.

4. Murphey MD, Walker EA, Wilson AJ, Kransdorf MJ, Temple HT, Gannon FH. Imaging of primary chondrosarcoma: radiologic-pathologic correlation. Radiographics. 2003;23(5):1245-78.

5. Hartrick CT, Kovan JP, Shapiro S. The numeric rating scale for clinical pain measurement: a ratio measure? Pain Pract. 2003;3(4):310-6.

6. Oshima J, Imai Y, Sasaki K, Sekido M. Giant ganglion cyst arising from iliac wing, an atypical site. Indian J Plast Surg. 2021. https://doi.org/10.1055/s0041-1725225.

7. Chatt N, Francois A, Acid S, Vande Berg B, Kirchgesner T. Giant intraosseous ganglion of the fibula: multimodality imaging. Skeletal Radiol. 2020:49(12):2063-7.

8. Maeba T, Kahara N. Intraosseous ganglion cyst of the sternoclavicular joint. PRS-Glob Open. 2020. https://doi.org/10.1097/GOX.0000000000 002708.

9. Crabbe W. Intra-osseous ganglia of bone. Br J Surg. 1966:53(1):15-7.

10. Schajowicz F, Clavel Sainz M, Slullitel JA. Juxta-articular bone cysts (intraosseous ganglia): a clinicopathological study of eighty-eight cases. J Bone Jt Surg Br Vol. 1979;61(1):107-16.

11. Coulier B, Devyver B, Hamels J. Imaging demonstration of fistulous gas communication between joint and ganglion of medial malleolus. Skeletal Radiol. 2002;31(1):57-60.

12. Sbai MA, Benzarti S, Boussen M, Msek H, Maalla R. Intraosseous ganglion cyst of the lunate: a case report. Chin J Traumatol. 2016;19(3):182-4.

13. Bennett DC, Hauck RM. Intraosseous ganglion of the lunate. Ann Plas Surg. 2002;48(4):439-42.

14. Al-Tarawneh E, Al-Qudah M, Hadidi F, Jubouri S, Hadidy A. Incidental intraosseous pneumatocyst with gas-density-fluid level in an 
adolescent: a case report and review of the literature. J Radiol Case Rep. 2014;8(3):16-22.

15. Bielecki DK, Sartoris D, Resnick D, Van Lom K, Fierer J, Haghighi P. Intraosseous and intradiscal gas in association with spinal infection: report of three cases. AJR Am J Roentgenol. 1986;147(1):83-6.

16. Maldague BE, Noel HM, Malghem JJ. The intravertebral vacuum cleft: a sign of ischemic vertebral collapse. Radiology. 1978;129(1):23-9.

17. Sander R. Compilation of Henry's law constants (version 4.0) for water as solvent. Atmos Chem Phys. 2015;15(8):4399-981.

18. Fitzek S, Engelmann C, Fitzek C. Vertebral pneumatization. Clin Neuroradiol. 2011;21(1):27-30.

\section{Publisher's Note}

Springer Nature remains neutral with regard to jurisdictional claims in published maps and institutional affiliations.

- fast, convenient online submission

- thorough peer review by experienced researchers in your field

- rapid publication on acceptance

- support for research data, including large and complex data types

- gold Open Access which fosters wider collaboration and increased citations

- maximum visibility for your research: over $100 \mathrm{M}$ website views per year

At $\mathrm{BMC}$, research is always in progress.

Learn more biomedcentral.com/submissions 